Acta Horticulturae et Regiotecturae 1

Nitra, Slovaca Universitas Agriculturae Nitriae, 2015, pp. 16-19

\title{
DETERMINATION OF PLANT AVAILABLE SOIL WATER STORAGE IN AGRICULTURAL LAND OF THE NITRA RIVER CATCHMENT
}

\author{
Andrej TÁRNÍK*, Dušan IGAZ \\ Slovak University of Agriculture in Nitra, Slovak Republic
}

\begin{abstract}
Soil water storage and its spatial pattern is one of the biggest tasks in agricultural field of study. Correct spatial interpretation and quantification of soil water storage are considered crucial for correct hydrological zonation of agricultural lands. This paper is focused on determination of amount of plants available soil water in the Nitra River Catchment in 2013. Available soil water storage was computed for each quarter of the year (I.-IV.; V.-VIII.; IX.-XII.) for $60 \mathrm{~cm}$ soil horizon. Amount of available water was determined as a difference between actual soil moisture and hydrolimits of water availability. Actual soil moisture was interpolated from point's values from net of hydrological stations in the Nitra River Catchment. Limited water availability was calculated by retention curves from soil samples taken in the Catchment. Available soil water storage was the highest in the first quarter $(36.74 \mathrm{~mm}$ ). In the second quarter, it decreased to $26.93 \mathrm{~mm}$ and in the third quarter it was only $4.11 \mathrm{~mm}$. In the fourth quarter, it increased to $30.13 \mathrm{~mm}$.
\end{abstract}

Keywords: available soil water, hydrolimits, limited water availability, the Nitra River Catchment

Water is subsumed into main natural resources. Life is not possible without water in that way as we know it. Water and soil are basic production resources for animal breeding and plant growing in agriculture. Soil water in root zone mainly is important for plants. Soil water along with surface and subsurface water belongs to three main water resources (Šútor and Rehák, 2009).

Ecosystems are sensitive to soil moisture changes. These changes, together with heat fluxes between the Earth surface and atmosphere are driving forces of weather and climate. Soil water storage in zone of aeration, especially in root zone is key variable for surface and subsurface water conditions and also for complete hydrological and energetic balance (Igaz, 2010).

As we mentioned above, soil water is the resource of water for plants. Soil water is bounded in soil so not the whole soil water volume is available for plants. In practice, it is necessary to observe and maintain soil moisture in limits of its availability for field plants. Availability of soil water for plants is determined by hydrolimit field capacity as an upper boundary and hydrolimit wilting point as a lower boundary (Antal and lgaz, 2012; Šútor and Štekauerová, 2001).

$$
\Theta_{A}=\Theta_{F C}-\Theta_{W P}
$$

where:

$\Theta_{A} \quad$ - plant available soil water

$\Theta_{F C} \quad$ - field capacity

$\Theta_{W P}$ - wilting point

This paper also deals with soil moisture and its availability for plants. Soil water storage available for plants was calculated on basis of soil samples analysis and data collected by the net of meteorological stations.

\section{Material and methods}

\section{Study area}

Our area of interest is the Nitra River Catchment which is the subcatchment of the Váh. The whole area of the Catchment lies in the Slovak Republic and its area is $5,080 \mathrm{~km}^{2}$. Northern and western part of the Nitra River Catchment border is common with the Váh River Catchment and the eastern one with the Hron River Catchment.

The Nitra River springs in the Malá Fatra Mountains and flows between the Strážovské vrchy and the mountain ranges of Tribeč and Vtáčnik. The river bed continues to the Podunajská pahorkatina, where the Nitrianska niva was created. The Nitra River is $172 \mathrm{~km}$ long and then it flows into the Váh River.

The area of interest is mainly agricultural land (61\% of area) and forests (30\% of area). The most common soil form by soil texture is moderate weight soil in the Nitra River Catchment. Average content of Cox is $1.5 \%$ with range 0.4-3.7\% (Horák et al., 2013). Soil types in our Catchment are represented mainly by Haplic Luvisols, Eutric Cambisols, Rendzic Leptosols in northern part and Chernozems and Mollic Fluvisols in southern part (Landscape Atlas of the Slovak Republic, 2014). 


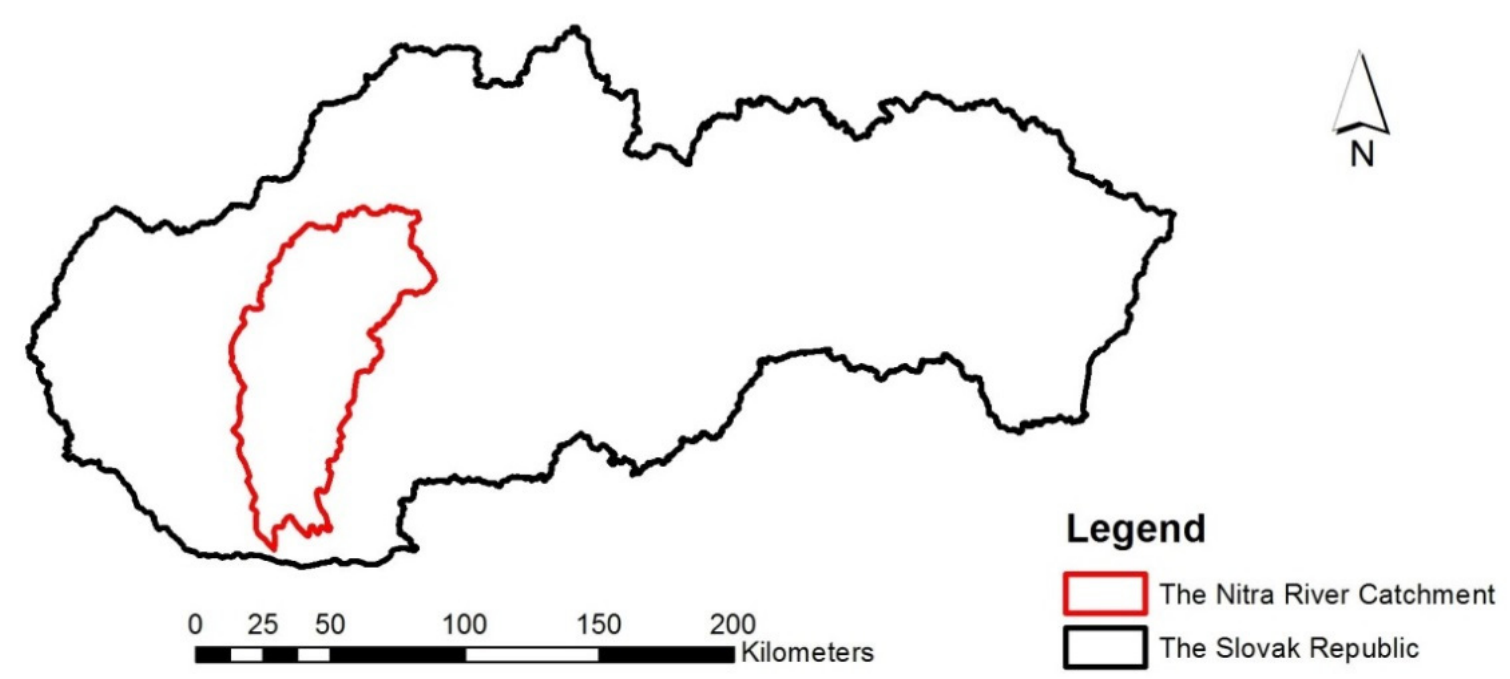

Figure 1 Location of Nitra River Catchment

\section{Data collecting}

The Department of Biometeorology and Hydrology within the Centre of Excellence for Integrated Management of Basin built up 6 fully-functional meteorological and 25 hydrological observation stations. These stations are evenly distributed in the whole Catchment. The stations are able to continuously measure main meteorological and hydrological parameters and also do on-line data transfer.

The meteorological stations are set up to measure air temperature, air humidity, wind speed, wind direction, global radiation, precipitation, evapotranspiration and depth of soil freezing.

The hydrological stations measure soil moisture in 10 various depth of soil profile $(10,20,30,40,50,75$, $100,150,200$ and $250 \mathrm{~cm})$. Sensors 10HS developed by Decagon Devices are used. These sensors are based on the Frequency Domain Reflectometry method. Accuracy of $10 \mathrm{HS}$ sensors in mineral soils is $\pm 0.03 \mathrm{~m}^{3} \mathrm{~m}^{-3}$ if standard calibration equation is used.

Soil samples were also taken from agricultural soil to determine soil properties. The samples were taken from 112 posts for sufficient representation of soil properties spatial variability. Analyses for hydro-physical properties of soil were done. Soil structure, bulk density, hydraulic conductivity, retention curves and Cox content were determined. Webserver HydroPhysics for online availability of soil properties data was launched by the Department.

\section{Determination of available soil water storage}

Plant available soil water storage was determined for soil profile with depth $60 \mathrm{~cm}$ in 2013 . Soil moisture was determined by data collected by hydrological stations net. Soil profile was divided into two horizons (0-30 and 30-60 $\mathrm{cm})$. Soil moisture was calculated by data from depth 10, 20, 30,40 and $50 \mathrm{~cm}$ for these two horizons. Year 2013 was divided into four time intervals (I.-III.; IV.-VI.; VII.-IX. and X.-XII.) for soil moisture temporal variability.

We had point data about soil moisture in various depths of soil from nets of station. Then we used GIS tools to interpolate point data to reach spatial information. Kriging tool was used to spatial interpolation. This tool is often used by many authors, for example Orfánus, 2005 or Lakhankar et al., 2010. Pecho (2014) says that kriging method has better precision for spatial interpolation in areas with distant point data. Resolution of output raster data is $200 \mathrm{~m}$.

Boundaries of plants available soil water (hydrolimits field capacity and wilting point) were estimated from soil characteristics from 112 sampling points. For these soils we estimated moisture retention curves. In pursuance of retention curves particular hydrolimits characteristics were calculated. Value for field capacity was estimated as 2.3 (200 cm w.c.) and for wilting point value was estimated as 4.18 (15 $000 \mathrm{~cm}$ w.c.).

Same as soil moisture point values were estimated hydrolimits point's values by kriging method for its spatial interpretation for agricultural land of the Nitra River Catchment. We used cell size $200 \times 200$ m for output raster. We calculated average plants available soil water storage for the Catchment from these spatial information.

By determining the difference among measured real soil moisture and hydrolimit moisture determining available soil water, and taking to account soil depth, we calculated plant available soil water storage.

$$
W_{P}=\left(\Theta_{M}-\Theta_{W P}\right) \times h_{p}
$$

where:

$$
\begin{array}{ll}
W_{P} & - \text { amount of available soil water }(\mathrm{mm}) \\
\Theta_{M} & - \text { soil moisture } \\
\Theta_{W P} & - \text { wilting point } \\
h_{p} & - \text { soil depth }(\mathrm{mm})
\end{array}
$$

\section{Results and discussion}

In this paper we have determined plant available soil water storage in effective horizon of agricultural lands in the Nitra River Catchment for 2013 through soil moisture and boundaries of soil water availability. Results of plant available soil water storage calculation were divided into 
Table 1 Average Plants Available Soil Water Storage in $\mathrm{mm}$

\begin{tabular}{|c|c|c|c|}
\hline Horizon & $0-30 \mathrm{~cm}$ & $30-60 \mathrm{~cm}$ & $0-60 \mathrm{~cm}$ \\
\hline January - March & 16.90 (63\%) & $19.84(66 \%)$ & $36.74(64 \%)$ \\
\hline April - June & $9.21(34 \%)$ & $17.72(59 \%)$ & $26.93(47 \%)$ \\
\hline July - September & deficit 1.09 (4\%) & $5.20(17 \%)$ & $4.11(7 \%)$ \\
\hline October - December & $14.81(55 \%)$ & $15.32(51 \%)$ & $30.13(53 \%)$ \\
\hline
\end{tabular}
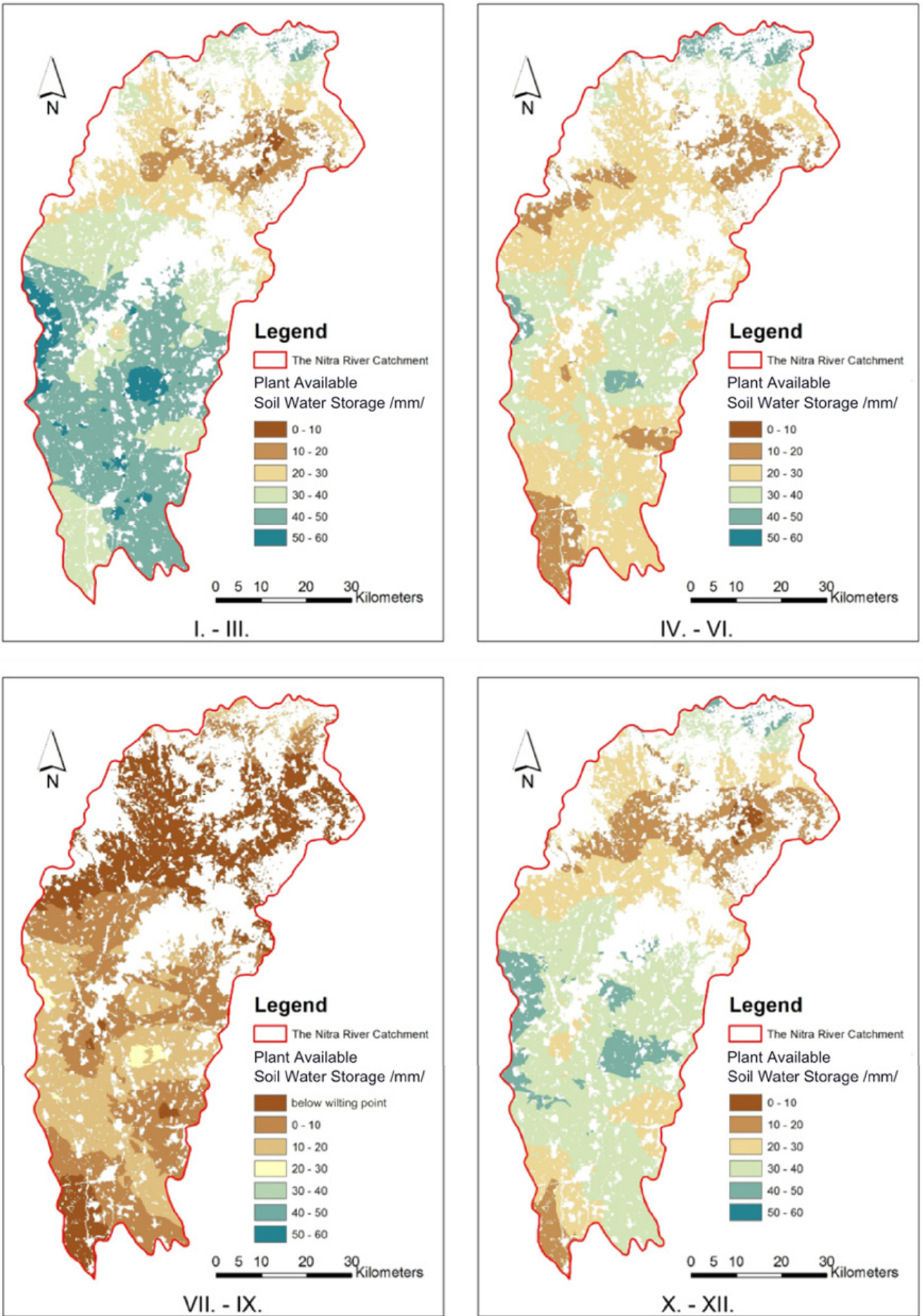

Figure 2 Average Plants Available Soil Water Storage $(0-60 \mathrm{~cm})$ 
Table 2 Average monthly precipitation totals in Nitra River Catchment per year 2013

\begin{tabular}{|l||c|c|c|c|c|c|c|c|c|c|c|c|}
\hline Month & I. & II. & III. & IV. & V. & VI. & VII. & VIII. & IX. & X. & XI. & XII. \\
\hline Precipitation in $\mathbf{~ m m ~}$ & 69.2 & 79.8 & 75.4 & 25.2 & 76.1 & 52.7 & 0.8 & 7.6 & 38.0 & 53.0 & 70.0 & 12.2 \\
\hline
\end{tabular}

4 time periods for 2013 (January - March, April - June, July September and October - December). Spatial interpretation of plant available soil water storage is represented by figure 2 .

Table 1 shows results of calculations divided into 2 soil horizons. Potential (maximum) plant available soil water storage in upper soil horizon is $27 \mathrm{~mm}$ and in lower horizon potential storage is $30 \mathrm{~mm}$.

By analysis of computed data we can say that the biggest plant available soil water storage was detected in the first time period from January to March (64\% of potential storage). The results of our research are supported by Pecho (2014). He said that summer and autumn of 2013 were extremely dry and warm. We see effects of these factors mainly in the third time period when plant available soil water storage decreased only to $7 \%$ of potential storage. In some areas there is less soil water than wilting point level as figure 2 shows. In these areas, the situation is critical for plants.

Table 2 shows average precipitation in the Nitra River Catchment per 2013 for overall view of meteorological condition in this area. We can see that rainfall was only $8.4 \mathrm{~mm}$ in months July and August (the third time period). Average monthly precipitation totals in the Nitra River Catchment were calculated as an average of data from meteorological stations Dolné Naštice and Nitra.

\section{Conclusion}

In this paper we are focused on one aspect of a very pressing environmental issue. We analysed soil moisture content and its temporal and spatial variability. Climate changes and irregular rainfall caused dry period with plant available soil water shortage. The results of this paper can be used for further analyses of moisture regime on agricultural soils in the Nitra River Catchment. From the obtained data we are able to analyse available soil water storage. We can suggest locations appropriate for crop production of certain type of agricultural plants. Analysing areas that are below wilting point we are able to design irrigation. These GIS analyses can be modelled for longer time periods, not only for one year.

\section{Acknowledgements}

This paper was supported by project APVV-0139-10 "Hydro physical characteristics spatial interpretation of Slovak soils in relation to their hydrological regime", project VEGA 2/0040/12 "Complex mathematical simulation of the water, heat energy and chemical substances motion in agricultural and forest biotopes, with emphasis upon extreme situations".

\section{References}

ANTAL, J. - IGAZ, D. 2012. Aplikovaná agrohydrológia. Nitra: SPU, 2012. ISBN 978-80-552-0731-5.

DECAGON DEVICES. 2014. [online], [cit. 2014-03-30]. Available at: <http://www.decagon.com/products/soils/volumetric-watercontent-sensors/10hs-soil-moisture-large-area-of-influence/>

HORÁK et al. 2013. Model estimates of nitrous oxide (N2O) emission from arable soils of Nitra region. In Veda mladých, 2013. ISBN 978-80-552-1081-0.

IGAZ, D. 2010. Pôdna vlhkost', jej tvorba a kvantifikácia: habilitačná práca. Nitra : SPU. 2010.

LANDSCAPE Atlas of the Slovak Republic. 2013 [online], [cit. 201303-30]. Available at: <http://geo.enviroportal.sk/atlassr/>

LAKHANKAR, T. et al. 2010. Analysis of Large Scale Spatial Variability of Soil Moisture Using a Geostatistical Method in Sensors. 2010, no. 10, pp. 913-932. ISSN 1424-8220.

ORFÁNUS, T. 2005. Spatial Assessment of Soil Drought Indicators at Regional Scale: Hydrolimits and Soil Water Storage Capacity in Záhorská nížina. In Journal of Hydrology and Hydromechanics, 2005, no. 3, pp. 164-176. ISSN 1338-4333.

$\mathrm{PECHO}$, J. 2014. Klimatické zhodnotenie roku 2013. [online], [cit. 2014-03-30]. Available at: <http://climatemap.blogspot. sk/2014/01/klimatologicke-zhodnotenie-roku-2013.html>

ŠÚTOR, J. - REHÁK, Š. 2009. Problematika vody v zóne aerácie pôdy s ohl'adom na integrovaný manažment povodí, súčasnú legislatívu a smernicu EÚ. In Acta Hydrologica Slovaca, 2009, no. 1, pp. 94-108. ISSN 1335-6291.

ŠÚTOR, J. - ŠTEKAUEROVÁ, V. 2001. Kvantifikácia zásob vody v zóne aerácie pôdy $v$ polnohospodárskych ekosystémoch - Využitie súborov údajov získaných monitoringom. In Acta Hydrologica Slovaca, 2001, no. 1, pp. 64-71. ISSN 1335-6291. 